\section{To theEditor:}

Stoneking ${ }^{1}$ writes that "Conroy ${ }^{2}$ may have misled some readers into thinking that there exists controversy over some basic aspects of mtDNA genetics, such as the meaning of the human mtDNA coalescent." Conroy, of course, notes that the controversies lie in the interpretations of mtDNA genetics, not in its basic aspects. What has confused the interpretation of mtDNA from the very start is the assertion that the meaning of the mtDNA coalescent is straightforward and very simple, solely reflecting time. ${ }^{3,4}$ But multiple factors affect the mtDNA coalescent, ${ }^{5}$ and comparisons with seemingly neutral nuclear DNA show that its meaning is far from straightforward. ${ }^{6}$ mtDNA is not a neutral system, ${ }^{7}$ which means that its variation cannot reflect time. While mtDNA most likely has been under selection, 8 the absence of similarly restricted variation in neutral autosomal genes ${ }^{6,8,9}$ shows that the selection acted only on this nonrecombining portion of the genome. ${ }^{10}$ This is the most significant violation of the assumptions underlying the original interpretation of restricted human mtDNA variation. Thus, it is the complexity reflected by the controversies created by alternative interpretations of the mtDNA coalescent that may be important for paleoanthropology, potentially shedding light on prehistoric population structure and other aspects of paleodemography. ${ }^{10,11}$

\section{REFERENCES}

1 Stoneking M. 1998. Letter to the editor. Evol Anthropol 7:80.

2 Conroy G. 1998. Paleoanthropology today. Evol Anthrop 6(5):155-156.

3 Stoneking M, Cann RL. 1989. African origins of human mitochondrial DNA. In: M ellars P, Stringer C, editors. The human revolution: behavioural and biological perspectives on the origins of modern humans. Edinburgh: Edinburgh University Press. p 17-30.

4 Cann RL, Stoneking M, Wilson AC. 1987. Mitochondrial DNA and human evolution. Nature 325:31-36.
5 Templeton AR. 1993. The "Eve" hypotheses: a genetic critique and reanalysis. Am Anthropol 95:51-72.

6 Hey I. 1997. Mitochondrial and nuclear genes present conflicting portraits of human origins. Mol Biol Evol 14:166-172.

7 Merriwether DA, Clark AG, Ballinger SW, Schurr TG, Soodyall H, J enkins T, Sherry ST, Wallace DC. 1991. The structure of human mitochondrial DNA variation.J Mol Evol 33:543-555. 8 Wise CA, Sraml M, Rubinsztein DC, Easteal S. 1997. Comparative nuclear and mitochondrial genome diversity in humans and chimpanzees. Mol Biol Evol 14:707-716.

9 Templeton AR. 1997. Testing the out of Africa replacement hypothesis with mitochondrial DNA data. In: Clark GA, Willermet CM, editors. Conceptual issues in modern human origins research. New York: Aldine de Gruyter. p 329-360, 437492.

10 Templeton AR. 1997. Out of Africa? What do genes tell us? Cur Opin Genet Dev 7:841-847.

11 Relethford JH. 1995. Genetics and modern human origins. Evol Anthropol 4:53-63.

Milford $\mathrm{H}$. Wolpoff and Rachel Caspari

Paleoanthropology Laboratory Department of Anthropology University of Michigan Ann Arbor, Ml 48109-1382 ( 1999 Wiley-Liss, Inc . 